\title{
Aquifer Geometry and Water Quality in Relation to Occurrence and Distribution of Peat in Baghia-Chanda Beel, Bangladesh
}

\author{
F. Ferdous ${ }^{1 *}$, M. R. Rafiq ${ }^{2}$, M. I. Mahmud ${ }^{2}$ \\ ${ }^{1}$ Department of Geology, University of Dhaka, Dhaka-1000, Bangladesh \\ ${ }^{2}$ Department of Geology and Mining, University of Barisal, Barisal, Bangladesh \\ Received 19 October 2015, accepted in final revised form 11 March 2016
}

\begin{abstract}
Baghia-Chanda Beel, largest peat basin in Madaripur and Gopalganj (Bangladesh) districts occupies thick deposits of peat. Study focuses on the aquifer geometry and geochemical evaluation of groundwater in relation to occurrence and distribution of peat. Landuse map is generated to show the surface distribution of peat. Thick peat and clay layer respectively, with an average thickness of $7 \mathrm{ft}$, has been observed throughout the study area. Principal productive aquifer about $40 \mathrm{ft}$ thick, is found at depth between 35 to $145 \mathrm{ft}$ below ground surface. According to $\mathrm{pH}$ and $\mathrm{EC}$ values, groundwater is mildly acidic to slightly alkaline and fresh to brackish. High bicarbonate concentration which is more likely to be attributed from the oxidative degradation of peat is found at shallow aquifer below peat. Elevated sodium $\left(\mathrm{Na}^{+}\right)$and chloride $\left(\mathrm{Cl}^{-}\right)$concentrations in deep aquifer are due to the trapping of ancient sea water in the subsurface during Quaternary period. Although deep aquifer is extensively low in arsenic, $68 \%$ and $44 \%$ shallow groundwater samples are arsenic (As) contaminated according to WHO, 2011 and Bangladesh Drinking Water Standard (DoE, 1997) limit respectively. Assessment of Water Quality Indexes (WQI>100) suggests that water from deep aquifer is more suitable for drinking purposes.
\end{abstract}

Keywords: Aquifer geometry; Hydrogeochemistry; Hydrogeology; Peat basin; Water quality.

(C) 2016 JSR Publications. ISSN: 2070-0237 (Print); 2070-0245 (Online). All rights reserved. doi: http://dx.doi.org/10.3329/jsr.v8i3.25360

J. Sci. Res. 8 (3), 355-370 (2016)

\section{Introduction}

Large deposit of peat was discovered in the north-eastern, middle and south-western parts of Bangladesh at Baghia-Chanda Beel in Madaripur and Gopalganj districts in 1953 [1]. It is a depressed swampy area in the deltaic flood plain and remains under water for a large period of the year. The peat basin area covers approximately $518 \mathrm{sq} \mathrm{km}$ of Baghia-Chanda Beel and is deeply flooded by rainwater during the monsoon period. During the rainy

* Corresponding author: lina.farzana@ hotmail.com 
season (July to November), the entire beel area is submerged under about 2 to $4 \mathrm{~m}$ of water, while during the dry season (January to May), the water table goes down to about 1 to $2 \mathrm{~m}$ below the surface [1]. The peat layer occurs at the surface or at very shallow depths ranging from few centimeters to maximum of $4 \mathrm{~m}$. The peat layer is generally 1 to $2 \mathrm{~m}$ thick, though its thickness ranges from few centimeters to a maximum of $4 \mathrm{~m}$. Groundwater below the peat layer can be contaminated by the percolation of rainwater through it. The aim of this study was to understand aquifer geometry and to assess the impact of overlying peat deposits on groundwater chemistry of the aquifer. Particular attention was given to evaluate the suitability of the groundwater for drinking purposes with reference to Bangladesh Drinking Water Standards [2] and World Health Organization's guideline value [3].

\subsection{Study area:}

The study area comprises Rajoir and Kotalipara upazilla in the north-eastern, middle and south-western part of Bangladesh is shown in Fig. 1. Geographically, Rajoir upazilla under Madaripur district is located between $23^{\circ} 06^{\prime}$ and $23^{\circ} 20^{\prime} \mathrm{N}$ and $89^{\circ} 56^{\prime}$ and $90^{\circ} 06^{\prime} \mathrm{E}$ with an aerial extent of 229.29 sq. km. Whereas, Kotalipara upazilla under Gopalganj district lies between $22^{\circ} 52^{\prime}$ and $23^{\circ} 08^{\prime} \mathrm{N}$ and $89^{\circ} 55^{\prime}$ and $89^{\circ} 08^{\prime} \mathrm{E}$ and it spreads over $362.05 \mathrm{sq} . \mathrm{km}$. The area is comprised three major climatic seasons: hot summer (MarchMay), monsoon or rainy season (June-October) and a moderate winter season (NovemberFebruary). The average annual rainfall in and around the study area is 1750 to $2000 \mathrm{~mm}$.
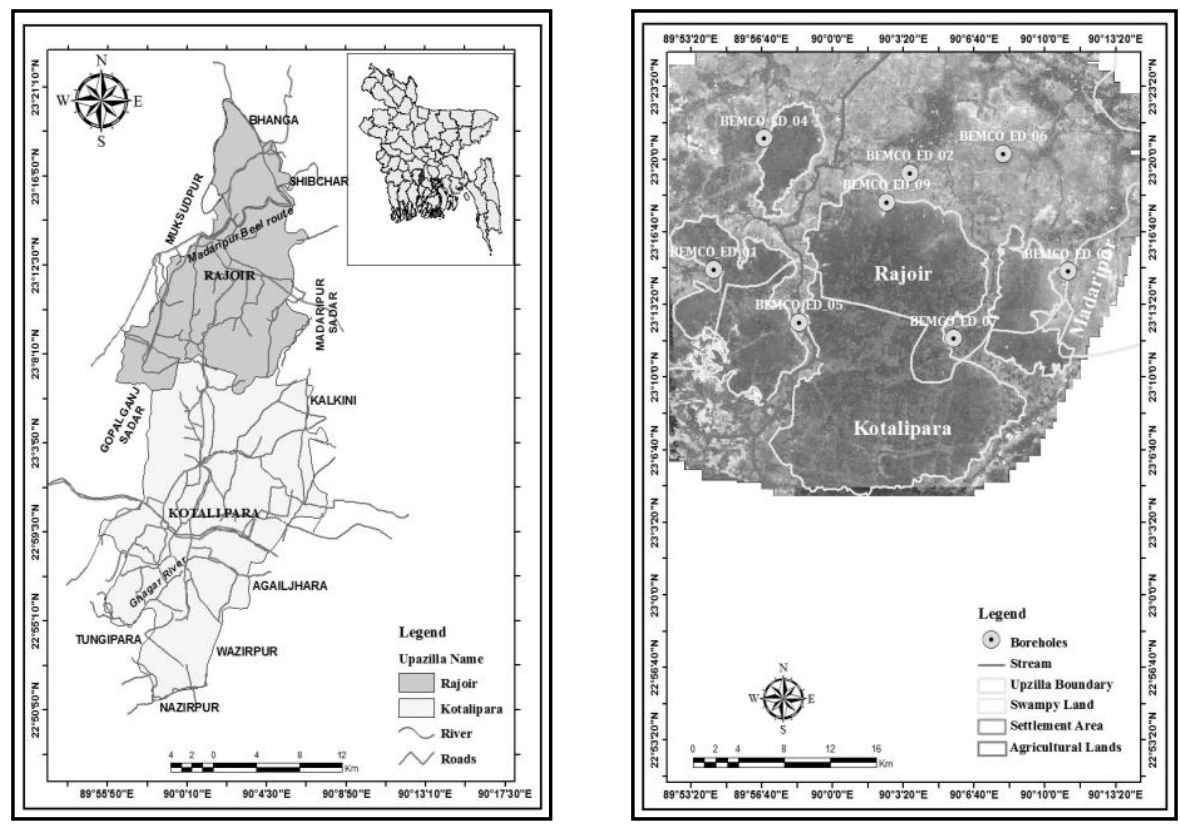

Fig. 1. Landuse map of the study area and locaton of boreholes. 


\section{Experimental}

An initial field survey was carried out at various locations throughout Rajoir and Kotalipara upazilla of Madaripur and Gopalganj districts respectively. A total of 36 groundwater samples from both shallow and deep tube wells were collected (Fig. 1). Hydrogen ion concentration $(\mathrm{pH})$, redox potential $(\mathrm{Eh})$, temperature and electrical conductivity (EC) were measured at the field, whereas the concentration of major cations and anions were analyzed at the laboratory as per the standard analytical procedures. High resolution Quick Bird satellite images downloaded from freely available Google Earth and remote sensing techniques were used to create landuse and land cover map of the study area based on these imageries. Four major classes (settlement area, swampy area, water bodies and agricultural lands) of polygonized images (Fig. 1) were developed according to the information required for the study. RockWorks $15 \AA$ software was used to evaluate subsurface aquifer geometry, nature of sediments as well as to construct lithological crosssections, strip-logs, startigraphic cross-sections and startigraphic models. All types of data were organized and processed in a logical way to prepare the diagram for visual representation.

\section{Results and Discussion}

\subsection{Aquifer geometry}

Characterization of aquifer geometry is important for understanding the subsurface structures and nature of the sediments. Striplogs and hydrostratigraphic models (Fig. 2) were generated to understand the vertical distribution of lithology down to the depth of 145 feet as well as to illustrate the general spatial trends in aquifer thickness and spatial variability in aquifer materials. Lithology of the logs consists of 12 types of unconsolidated sediment: bluish grey clay, grey silt with clay, bluish grey silty clay, light brown silty clay, fine sand with clay, fine sand with silt, fine sand, grey fine to medium sand, medium sand, grey medium sand with clay, grey medium to coarse sand, and peat. Light brown silty clay, which is continuous throughout the area, is observed at the top of most of the striplogs. Peat material, underlain by bluish grey silty clay and bluish grey clay, is found in all the borelogs but two with variable thicknesses at depths ranges from 5 to $15 \mathrm{ft}$. Sand layers, having various grain sizes, is usually found at depths 35 to $145 \mathrm{ft}$.

Hydrostratigraphic models (Fig. 2) of the study area exhibit three types of hydrostratigraphy. The uppermost silty clay layer serves as first aquitard varies in thickness from 5 to $10 \mathrm{ft}$ throughout the area. This aquitard overlies a peat layer of $5 \mathrm{ft}$ thick which is thinner along the western and southern portions and gradually increases to about 8 to $9 \mathrm{ft}$ towards eastern and northern portion of the study area.

Another aquitard lying below the peat layer is a continuous layer throughout the study area and it shows its average thickness of about $80 \mathrm{ft}$ along the north-eastern part and its thickness decreases towards west-central and south-central portions. The first shallow aquifer (aquifer-1) is very thick, 40 feet on average, in most of the places, but it is very 
thin at the north-central portion. The third aquitard starts from the depth of $75 \mathrm{ft}$ and extends down to the depth of $145 \mathrm{ft}$ and its thickness ranges from 5 to $10 \mathrm{ft}$. The second shallow aquifer (aquifer-2), which overlies fourth aquitard only at the north-eastern portion, is mainly found at the eastern, south-eastern and north-eastern portions of the study area. Table 1 gives an overview of the hydrostratigraphy of the study area.

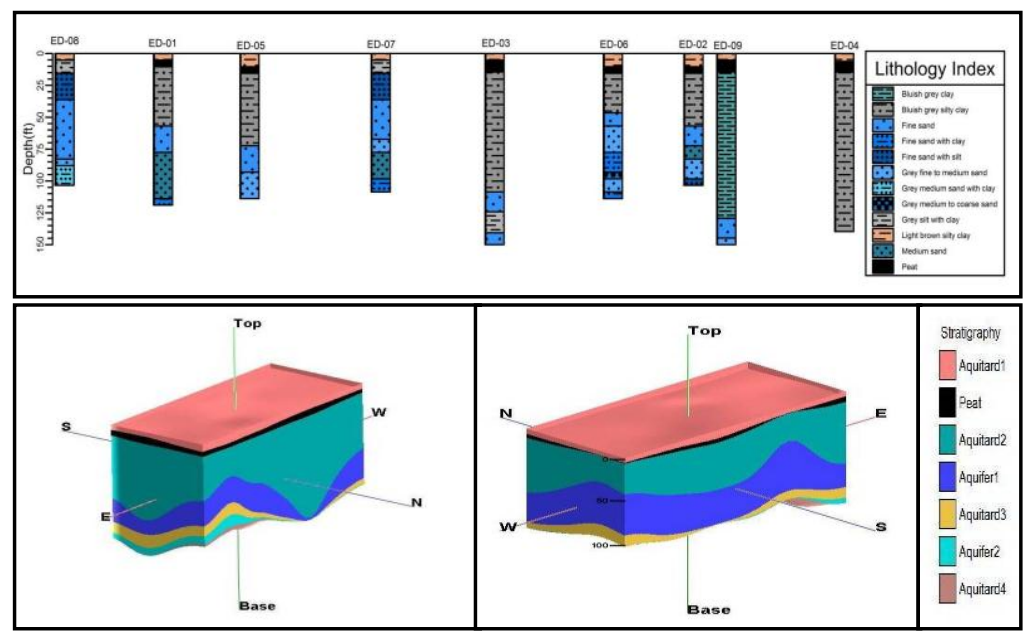

Fig. 2. Striplogs of boreholes (top) and hydrostartigraphic models (bottom, SW and NE view).

Table 1. Hydrostratigraphic succession of the peat basin.

\begin{tabular}{llll}
\hline Units & Hydrostratigraphic Unit & Average Thickness (ft) & Lithology \\
\hline Unit-1 & Aquitard-1 & 8 & Light brown silty clay \\
Unit-2 & Peat & 7 & Peaty soil \\
Unit-3 & Aquitard-2 & 80 & Bluish grey silty clay \\
Unit-4 & Aquifer-1 & 40 & Medium to fine sand \\
Unit-5 & Aquitard-3 & 10 & Fine sand with clay \\
Unit-6 & Aquifer-2 & 10 & Fine to coarse sand \\
Unit-7 & Aquitard-4 & 3 & Fine sand with clay \\
\hline
\end{tabular}

\subsubsection{Peat thickness}

The depth contour map of peat layer (Fig. 3a) shows that it occurs at very shallow depths and it is expected that the thickness of the peat material is reducing with time due to continuous decomposition processes. According to the contour map of peat thickness (Fig. $3 b$ ), The thickest peat layer ( $9 \mathrm{ft}$ thick) is found at shallow depth (5 to $6 \mathrm{ft}$ depth) in the south-eastern and eastern portions of Rajoir upazila, while the thinnest peat layer $(5 \mathrm{ft}$ thick) is found at greater depth (7 to $10 \mathrm{ft}$ depth) in the northern portion of Kotalipara upazila. 

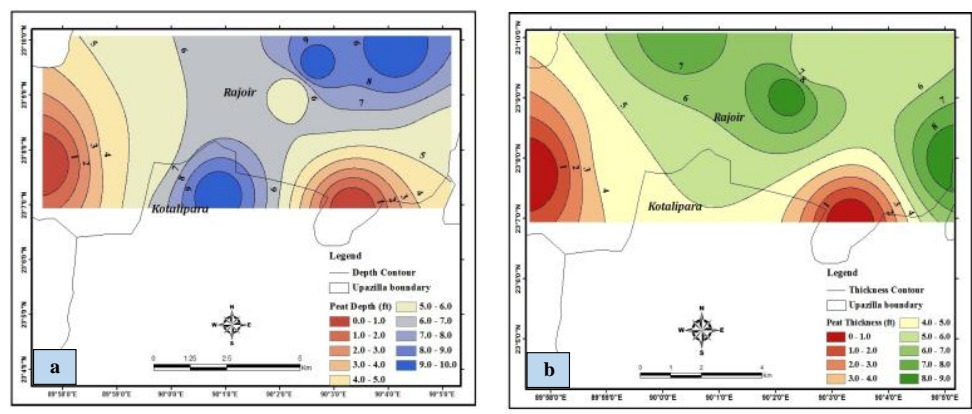

Fig. 3. a) Peat depth contour map of the study area, b) Peat thickness contour map of the study area.

\subsubsection{Clay thickness}

3D diagrams of peat layer and top two clay layers are presented in Fig. 4. Both clay and peat layers show some variations in thickness. The top clay layer is much thicker, ranges from 8 to 10 feet from ground surface, at the north-eastern (Rajoir) and middle-southern (Kotalipara) portions of the area. Two depressions or wet basins somewhat at the central of the area show low thickness of top clay layer. Moreover, northern, western, and southeastern portions are relatively flat where thickness of the top clay layer varies from 5 to 10 feet. Clay layer immediately below the peat material displays greater thicknesses throughout the area. In the north-eastern part, highest clay thicknesses, ranging from 15 to 135 feet below the peat deposits, are detected. There are some places such as northeastern, north-western, south-eastern parts of the study area where thickness of the second clay layer is very low. Between these two clay layers, peat layer is observed throughout the area with some variations in thickness.

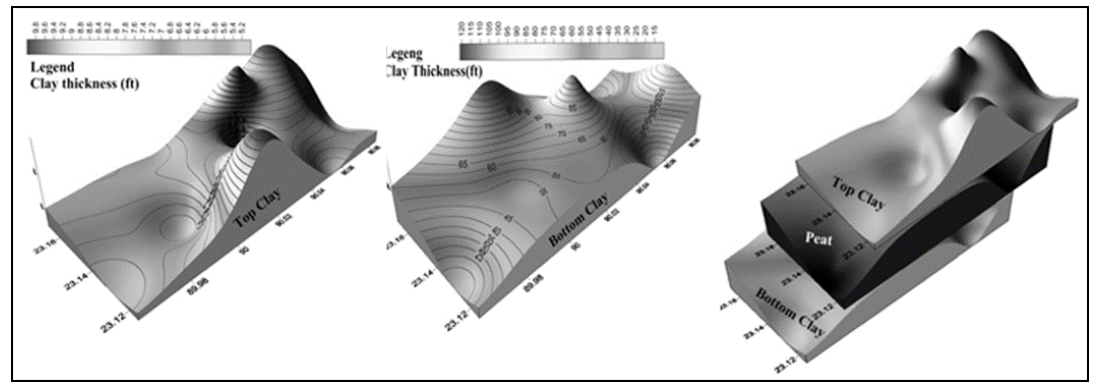

Fig. 4. 3D overview of peat and clay thickness.

\subsection{Hydrogeochemistry}

Groundwater samples were collected from 36 tubewells in the study area during dry period (December 2011). The $\mathrm{pH}$, Eh, and EC were measured in the field, whereas the concentration of major ions, minor ions and trace constituents were analyzed at the laboratory as per the standard analytical procedures. 


\subsubsection{On-site parameters}

The physico-chemical state of groundwater is generally defined in terms of their temperature, EC, pH, and Eh. These parameters are usually measured on-site in the field during sampling. The temperature of groundwater samples in the study area ranged from $23.9^{\circ} \mathrm{C}$ to $26.6^{\circ} \mathrm{C}$. The groundwater samples collected from shallow tube wells showed EC values between $850 \mu \mathrm{S} / \mathrm{cm}$ and $3790 \mu \mathrm{S} / \mathrm{cm}$, whereas deep tubewells showed relatively higher range $(1400 \mu \mathrm{S} / \mathrm{cm}$ to $4320 \mu \mathrm{S} / \mathrm{cm})$ of EC values. Shallow tubewells in the south-eastern part of Rajoir upazilla were characterized by high EC values ranged from $2000 \mu \mathrm{S} / \mathrm{cm}$ to $4000 \mu \mathrm{S} / \mathrm{cm}$, whereas, southern part of Rajoir and northern portion of Kotalipara upazilla showed relatively low EC values ranged from $1000 \mu \mathrm{S} / \mathrm{cm}$ to 2000 $\mu \mathrm{S} / \mathrm{cm}$. $\mathrm{pH}$ values recorded from the groundwater samples varied from 6.57 to 7.25 in shallow tubewells and from 6.85 to 7.41 in deep tubewells. It reveals that groundwater in the study area is slightly acidic to slightly alkaline and $\mathrm{pH}$ is relatively higher in deep aquifer than shallow aquifer. The redox potential of groundwater ranged from $-21 \mathrm{mV}$ to $111 \mathrm{mV}$. The negative values of Eh suggested that groundwater is in reducing condition. That the medium value of $-77 \mathrm{mV}$ in shallow tubewells and $-44 \mathrm{mV}$ in deep tubewells, according to box and whisker plot of Eh values, suggested groundwater in shallow aquifer is in more reducing condition than that of deep aquifer.

\subsubsection{Major ions chemistry}

The dominant naturally occurring constituents that used to assess groundwater compositions are anions: bicarbonate $\left(\mathrm{HCO}_{3}{ }^{-}\right)$, chloride $\left(\mathrm{Cl}^{-}\right)$, sulphate $\left(\mathrm{SO}_{4}{ }^{2-}\right)$ and nitrate $\left(\mathrm{NO}_{3}{ }^{-}\right)$and cations: calcium $\left(\mathrm{Ca}^{2+}\right)$, magnesium $\left(\mathrm{Mg}^{2+}\right)$, sodium $\left(\mathrm{Na}^{+}\right)$, and potassium $\left(\mathrm{K}^{+}\right)$. Relative abundance of major ions in the groundwater samples of shallow and deep tubewells are observed as shown in Figs. 5-6. The abundance of major cations are in the order of $\mathrm{Na}^{+}>\mathrm{Ca}^{2+}>\mathrm{Mg}^{2+}>\mathrm{K}^{+}$in both shallow and deep aquifer but abundance of major anions are in the order of $\mathrm{HCO}_{3}{ }^{-}>\mathrm{Cl}^{-}>\mathrm{NO}_{3}{ }^{-}>\mathrm{SO}_{4}{ }^{2-}$ in shallow aquifer and $\mathrm{Cl}^{-}>\mathrm{HCO}_{3}{ }^{-}$ $>\mathrm{NO}_{3}{ }^{-}>\mathrm{SO}_{4}{ }^{2-}$ in deep aquifer.
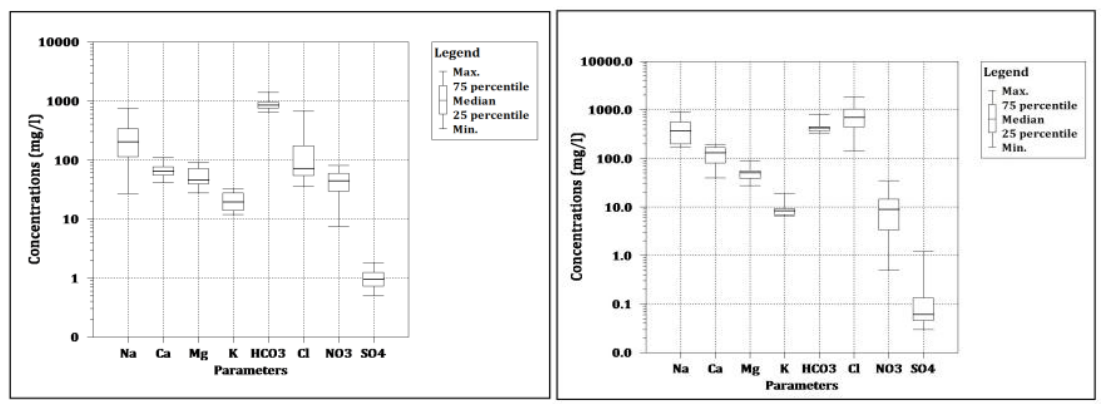

Fig. 5. Box and whisker plot showing major ions concentration range of a) shallow tube wells and b) deep tube wells (concentrations are displayed in log scale). 
Sodium concentration is comparatively higher in deep tubewells than that in shallow tubewells. Sodium concentration varied from $26.742 \mathrm{mg} / \mathrm{L}$ to $747.63 \mathrm{mg} / \mathrm{L}$ in shallow tubewells and from $173 \mathrm{mg} / \mathrm{L}$ to $910.02 \mathrm{mg} / \mathrm{L}$ in deep tubewells with median values of $206.33 \mathrm{mg} / \mathrm{L}$ and $395.48 \mathrm{mg} / \mathrm{L}$ respectively (Figs. 5a and $5 \mathrm{~b}$ ). Calcium concentration is also higher in deep tubewells than shallow tubewells and median values, are $132.44 \mathrm{mg} / \mathrm{L}$ and $63.65 \mathrm{mg} / \mathrm{L}$ for deep and shallow tubewells respectively (Fig. 5a \& 5b). Magnesium concentration, correspondingly, in shallow and deep tubewells ranged from $27.60 \mathrm{mg} / \mathrm{L}$ to $91.69 \mathrm{mg} / \mathrm{L}$ ) and from $27.76 \mathrm{mg} / \mathrm{L}$ to $88.8 \mathrm{mg} / \mathrm{L}$. Potassium concentration is lower in deep tubewells $(6.50 \mathrm{mg} / \mathrm{L}$ to $18.75 \mathrm{mg} / \mathrm{L})$ than in shallow tubewells $(11.88 \mathrm{mg} / \mathrm{L}$ to $33 \mathrm{mg} / \mathrm{L})$. Bicarbonate concentrations in groundwater samples of shallow tubewells showed higher concentration about $1387 \mathrm{mg} / \mathrm{L}$ whereas deep tube wells showed lower range from 335.50 $\mathrm{mg} / \mathrm{L}$ to $808.25 \mathrm{mg} / \mathrm{L}$. Groundwater samples collected from the shallow tube wells showed higher ranges $(>1200 \mathrm{mg} / \mathrm{L})$ in the south-eastern part of Rajoir upazilla where peat occured at shallow depth with great thickness. The concentration of bicarbonate in the study area ranged from less than $400 \mathrm{mg} / \mathrm{L}$ to greater than $500 \mathrm{mg} / \mathrm{L}$ in the deep tube wells. The highest bicarbonate concentrations are recorded at southern portion of Rajoir and Kotalipara upazilla from two groundwater samples whereas the lowest is recorded at only Rajoir. Shallow, younger water typically contained higher concentrations of chloride ions than deeper, older water. But in the study area all deep tubewells showed high chloride concentrations (ranged from $142 \mathrm{mg} / \mathrm{L}$ to1819 mg/L) while shallow tubewells exhibited comparatively low concentrations (ranged from $35.5 \mathrm{mg} / \mathrm{L}$ to $666.25 \mathrm{mg} / \mathrm{L}$ ) (Figs. 5a \& 5b). All shallow tubewells groundwater samples characterized by high nitrate concentrations, ranging from $7.50 \mathrm{mg} / \mathrm{L}$ to $80 \mathrm{mg} / \mathrm{L}$, and deep tubewells had low nitrate concentrations, ranged from $0 \mathrm{mg} / \mathrm{L}$ to $35 \mathrm{mg} / \mathrm{L}$, (Figs. $5 \mathrm{a}$ and $5 \mathrm{~b}$ ). Groundwater samples of shallow tube wells illustrated higher sulphate concentrations ranged from $0.5 \mathrm{mg} / \mathrm{L}$ to $1.80 \mathrm{mg} / \mathrm{L}$, whereas deep tubewells showed comparatively low concentrations ranged between $0.03 \mathrm{mg} / \mathrm{L}$ and $1.20 \mathrm{mg} / \mathrm{L}$.

\subsubsection{Minor ions and trace constituents}

Analyzed minor and trace constituents included $\mathrm{As}, \mathrm{Fe}, \mathrm{Mn}, \mathrm{Zn}$ and $\mathrm{Cd}$. Iron concentration in groundwater samples collected from the study area ranged from 0.23 $\mathrm{mg} / \mathrm{L}$ to $3.79 \mathrm{mg} / \mathrm{L}$. In the study area, manganese concentrations are not very high as all wells have concentrations less than $0.1 \mathrm{mg} / \mathrm{L}$. Manganese concentration in groundwater samples ranged from $0.03 \mathrm{mg} / \mathrm{L}$ to $0.1 \mathrm{mg} / \mathrm{L}$ whereas all the deep wells have low manganese concentrations. Arsenic is a common element in the Earth's crust, and occured naturally throughout the study area. There is a probability of arsenic mobilization from clayey and peaty sediments. The role of peat or organic matter is very significant in mobilization of arsenic (As) in groundwater. High concentration of As in the shallow aquifer might have been mobilized due to microbially mediated reductive dissolution of iron oxyhydroxide $(\mathrm{FeOOH})[4,5,6]$. Higher amount of organic matter present in the peat soil can facilitate such reaction. All the shallow tube wells, groundwater samples 
contained arsenic at lower range $(<150 \mu \mathrm{g} / \mathrm{L})$ with median value $35 \mu \mathrm{g} / \mathrm{L}$ and almost all the deep tube well is free from arsenic, except one. The higher concentrations are found at the shallow depths of wells whereas at the higher depths observed very low arsenic concentrations.

\subsubsection{Hydrogeochemical facies of groundwater}

The diagnostic chemical character of water solutions in hydrologic systems has been determined with the application of the concept of hydrochemical facies, which enables a convenient subdivision of water compositions by identifiable categories and reflects the effect of chemical processes occurring between the minerals within the subsurface rock units and the groundwater.

Piper Trilinear Plotting: The Piper Trilinear diagram [7] was used to characterize the water types present in the area. The chemical composition of groundwater samples from the study area is shown on the Piper diagram (Fig. 6). Trilinear analysis suggests that most of the water samples collected from shallow tube wells show $\mathrm{Ca}-\mathrm{Mg}-\mathrm{HCO}_{3}-\mathrm{Cl}$ facies that indicates mixed type of water, while few of them show $\mathrm{Na}-\mathrm{HCO}_{3}$ facies indicating alkali carbonate type water. Some of groundwater samples collected from shallow tube wells showed $\mathrm{Ca}-\mathrm{Mg}-\mathrm{HCO}_{3}$ facies indicate freshly recharged water. In contrast to the groundwater samples collected from deep tube wells belong to the $\mathrm{Na}-\mathrm{Cl}$ facies indicating saline water, except two.

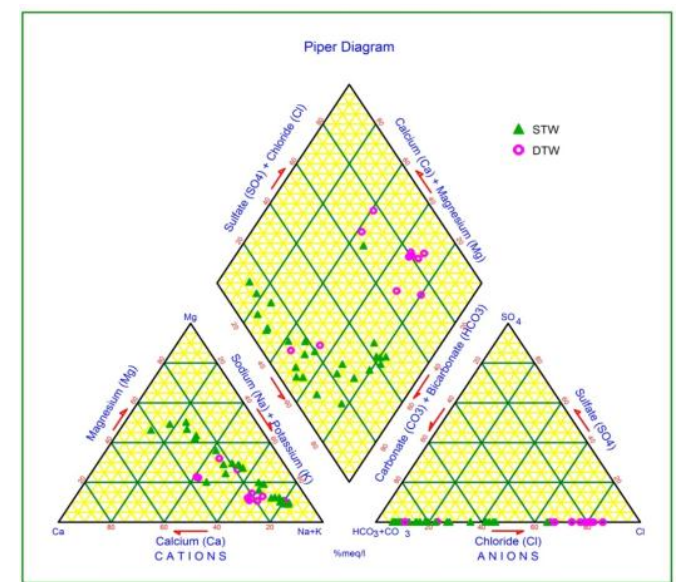

Fig. 6. Hydrochemical facies of the groundwater samples of different sources.

\subsubsection{Source rock deduction}

The purpose of source rock deduction is to gain insight into the possible origin of water analysis. Water moves through the ground will react into varying degrees with the surrounding minerals (and other components), and the rock-water interactions that give 
the water its characteristic chemistry. During rock weathering the major cations and anions are added to the water.

As there is no silica analysis result in any of the samples, simple ionic comparisons have been used for the analysis of source rock deduction after Hounslow, 1995 [8]. The ionic comparisons applied in the source rock deduction analysis are:

- $\quad$ TDS

- $\mathrm{Na}^{+} /\left(\mathrm{Na}^{+}+\mathrm{Cl}^{-}\right)$

- $\mathrm{Cl}^{-} /$Sum of anions

- $\mathrm{HCO}_{3}{ }^{-} / \mathrm{Sum}$ of anions

- $\mathrm{HCO}_{3}{ }^{-} /\left(\mathrm{Ca}^{2+}+\mathrm{Mg}^{2+}\right)$

This simplistic mass balance approach to deduce the source rock can be very helpful in understanding the origin of the groundwater. Interpretation of groundwater chemical data and the source rock analysis would help to deduce the probable source rock and influence of peat basin in groundwater composition.

TDS values indicate carbonate weathering or brine or seawater in all of the samples as the values are $>500 \mathrm{mg} / \mathrm{L}$.

The first comparison is to evaluate the relationship between sodium and chloride, to differentiate the source of $\mathrm{Na}^{+}$in the groundwater. The ionic ratio of $\mathrm{Na}^{+} /\left(\mathrm{Na}^{+}+\mathrm{Cl}^{-}\right)$ indicates whether the source of $\mathrm{Na}^{+}$is halite (the ratio will be zero or close to zero) or other than halite.

The calculated values of the ionic ratio of $\mathrm{Na}^{+} /\left(\mathrm{Na}^{+}+\mathrm{Cl}^{-}\right)$as shown in Fig. 7a for all the water samples (except one) of shallow tube wells showed ionic ratio $>0.5$ indicating sodium source other than halite such as albite weathering, ion exchange or natural softening as the following;

$\mathrm{NaAlSi}_{3} \mathrm{O}_{8}+\mathrm{H}_{2} \mathrm{CO}_{3}+{ }^{9} / 2 \mathrm{H}_{2} \mathrm{O} \rightarrow \mathrm{Na}^{+}+\mathrm{HCO}_{3}^{-}+2 \mathrm{H}_{4} \mathrm{SiO}_{4}+1 / 2 \mathrm{Al}_{2} \mathrm{Si}_{2} \mathrm{O}_{5}(\mathrm{OH})_{4}$ (Albite weathering) (1)

$\mathrm{Ca}^{2+}+2 \mathrm{Na}-\mathrm{Clay} \longrightarrow 2 \mathrm{Na}^{+}+\mathrm{Ca}-\mathrm{Clay}$

Water samples collected from deep tube wells indicate reverse softening (brine sea water) as all the values are $<0.5$. Thus, it can be deduced that reverse natural softening is likely to have taken place in the deep aquifer and consumes $\mathrm{Na}^{+}$ions and releases $\mathrm{Ca}^{2+}$ as shown in the following equation;

$2 \mathrm{Na}^{+}+\mathrm{Ca}-\mathrm{Clay} \longrightarrow \mathrm{Ca}^{2+}+2 \mathrm{Na}-\mathrm{Clay}$

The reverse ion exchange indicates presence of Ca-clay mineral with adequate exchange capacity and high $\mathrm{Na}^{+}$in water i.e. saline water [9] in the deep aquifer system.

The second comparison is between $\mathrm{Cl}^{-}$and sum of anions $\left(\mathrm{Cl}^{-} / \mathrm{Sum}\right.$ of anions) to identify the source of chloride in groundwater assuming that the primary source of chloride is from seawater, or brine, or evaporates from rainwater or generally is the result of rock weathering. 
The ratio of $\mathrm{Cl}^{-}$and sum of anions in Fig. $7 \mathrm{~b}$ indicate that $\mathrm{Cl}^{-}$in all the water samples of shallow tube wells and in most of the samples of deep tube wells with ratio $<0.8$ is resulted from mainly rock weathering while four water samples of deep tube wells with the ratio $>0.8$ and high TDS (> $500 \mathrm{mg} / \mathrm{L}$ ) indicate seawater source of $\mathrm{Cl}^{-}$.

The ratio of $\mathrm{HCO}_{3}{ }^{-}$and sum of anions $\left(\mathrm{HCO}_{3}{ }^{-} / \mathrm{Sum}\right.$ of anions) illustrated in Fig. $7 \mathrm{c}$ are mostly $<0.8$ for deep tube well water samples and few shallow tube well samples, which indicate seawater or brine as sulfate concentration is found low in most of the samples. Other water samples collected from shallow tube wells with values $>0.8$ indicate silicate or carbonate weathering.

The distribution of samples in $\left(\mathrm{Ca}^{2+}+\mathrm{Mg}^{2+}\right)$ vs. $\mathrm{HCO}_{3}{ }^{-}$plot shown in Fig. $7 \mathrm{~d}$ indicates the carbonate weathering is not dominant either in shallow or deep aquifer system as most the samples fall away from the 1:1 line (equiline). Almost all of the samples (except six water samples) of shallow tube wells that fall well below equiline indicating silicate weathering. The samples of deep tube wells above the 1:1 line (equiline) are probably enriched in $\mathrm{Mg}^{2+}$, indicating seawater influence. Higher $\mathrm{HCO}_{3}{ }^{-}$concentration relative to the $\mathrm{Ca}^{2+}$ and $\mathrm{Mg}^{2+}$ in the shallow aquifer suggest that in addition to silicate weathering oxidative degradation of organic matter (peat) is the probable source of high $\mathrm{HCO}_{3}{ }^{-}$in the shallow aquifer $[4,5,6]$.

The decay of organic matter promotes $\mathrm{CO}_{2}$ generation.

$\mathrm{O}_{2}+\mathrm{CH}_{2} \mathrm{O}$ (Organic matter $)=\mathrm{CO}_{2}+\mathrm{H}_{2} \mathrm{O}$

The $\mathrm{CO}_{2}$ then combines with $\mathrm{H}_{2} \mathrm{O}$ to produce $\mathrm{H}_{2} \mathrm{CO}_{3}$ and $\mathrm{HCO}_{3}{ }^{-}$as following:

$$
\mathrm{CO}_{2}+\mathrm{H}_{2} \mathrm{O} \longrightarrow \mathrm{H}_{2} \mathrm{CO}_{3} \longrightarrow \mathrm{H}^{+}+\mathrm{HCO}_{3}^{-}
$$

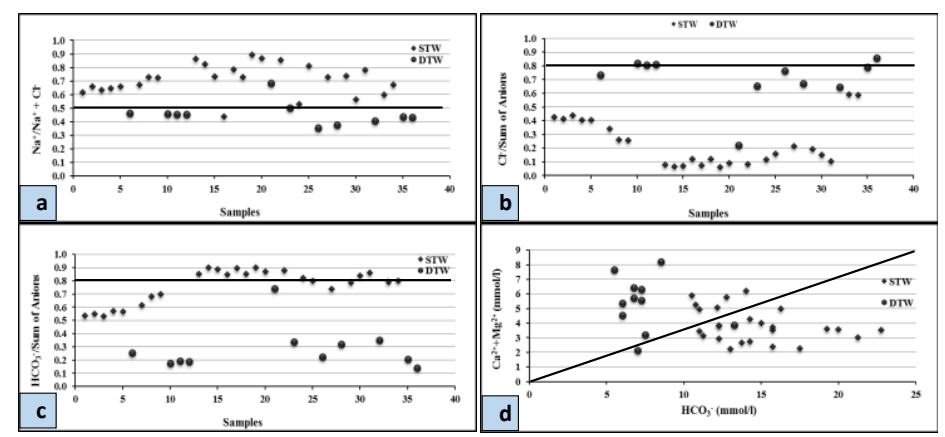

Fig. 7. a) $\mathrm{Na}^{+} / \mathrm{Na}^{+}+\mathrm{Cl}^{-}$ratio for each sample; b) $\mathrm{Cl}^{-} / \mathrm{Sum}$ of anions ratio for each sample; c) $\mathrm{HCO}_{3}{ }^{-}$ /Sum of anions ratio for each sample; d) $\left(\mathrm{Ca}^{2+}+\mathrm{Mg}^{2+}\right)$ vs. $\mathrm{HCO}_{3}^{-}$plot.

Therefore, it can be inferred from the source rock deduction analysis that silicate weathering and ion exchange are the dominant geochemical processes in the shallow aquifer system. The high $\mathrm{HCO}_{3}{ }^{-}$concentrations in the shallow aquifers are not likely from the carbonate weathering as indicated by molar ratio of $\left(\mathrm{Ca}^{2+}+\mathrm{Mg}^{2+}\right)$ vs. $\mathrm{HCO}_{3}{ }^{-}$(Fig. $7 \mathrm{~d}$ ) but may be attributed from oxidative degradation of peat that lies just above the shallow aquifer. On the other hand, influence of seawater is evident in the deep aquifer together 
with simple rock weathering. The presence of seawater in the deep aquifer system in the study area which is away from present day coast line can be explained by the trapped seawater which entered the aquifer during Quaternary Period when the relative position of land and sea were different from present.

\subsubsection{Drinking water quality}

In this research, assessment of the suitability for drinking purposes was evaluated by comparing the hydrochemical parameters of groundwater in the study area with the prescribed specification of WHO, 2011 [10] and DoE, 1997) [2]. Total dissolved solids (TDS) and hardness of most of the groundwater samples do not meet the water quality standards of WHO, 2011 [10]. About $72 \%$ both type of the groundwater samples analyzed are found within above the desirable limits of TDS set by WHO standards. The determined total hardness in shallow tube well groundwater samples varies from 222.52 $\mathrm{mg} / \mathrm{L}$ to $619.78 \mathrm{mg} / \mathrm{L}$ and $216.45 \mathrm{mg} / \mathrm{L}$ to $824.16 \mathrm{mg} / \mathrm{L}$ in deep tube wells. A few groundwater samples recorded hardness values above the recommended limit of $500 \mathrm{mg} / \mathrm{L}$ $\mathrm{CaCO}_{3}$ for drinking water by WHO, 2011 [10] and DoE, 1997 [2]. Concentrations of sodium ions are exceeding the prescribed limit of $200 \mathrm{mg} / \mathrm{L}$ in $52 \%$ and $81 \%$ of the analyzed shallow tube well and deep tube well groundwater samples respectively and the same numbers of samples have exceeded DoE, 1997 [2] standard. In all of the sampling stations calcium $\left(\mathrm{Ca}^{2+}\right)$ and magnesium $\left(\mathrm{Mg}^{2+}\right)$ fall within the standard desirable limit of WHO, 2011 [10]. Most of the deep tube well samples have higher concentrations than DoE, 1997 [2] standard limit and 88\% shallow tube well groundwater samples have exceeded $\mathrm{Mg}^{2+}$ standard limit of DoE, 1997 [2]. The chloride $\left(\mathrm{Cl}^{-}\right)$value is from 35.5 to $666.25 \mathrm{mg} / \mathrm{L}$ in shallow tube well groundwater samples and $142 \mathrm{mg} / \mathrm{L}$ to $1819.37 \mathrm{mg} / \mathrm{L}$ in deep tube well samples. In drinking water, the concentration of chloride should not exceed $250 \mathrm{mg} / \mathrm{L}$ as recommended by WHO, 2011 [10]. However, about 90\% deep tube well groundwater samples recorded higher chloride values (> $250 \mathrm{mg} / \mathrm{L}$ ). Only few shallow tube well samples show higher concentrations of chloride. The amount of chloride ions acceptable by DoE, 1997 [2] is above $600 \mathrm{mg} / \mathrm{L}$. But few number of samples exceed DoE, 1997 [2] standard. Excess concentration of chloride in drinking water gives a salty taste. Nitrate $\left(\mathrm{NO}_{3}{ }^{-}\right)$in drinking water should not exceed $50 \mathrm{mg} / \mathrm{L} \mathrm{[10].} \mathrm{48 \%} \mathrm{groundwater}$ samples of shallow tube wells recorded higher nitrate $\left(\mathrm{NO}_{3}{ }^{-}\right)$values exceed WHO, 2011 [10] drinking water standard limit. Only the deep tube wells are safe in this point. But according to DoE, 1997 [2] standard limit most of the shallow tube well samples exceeding standard limit. The values of sulphate $\left(\mathrm{SO}_{4}{ }^{2-}\right)$ concentrations in all the groundwater samples do not cross the standard limit of WHO, 2011 [10] and desirable limit of WHO, 2011 [10] and DoE, 1997 [2] standard. The groundwater of the deep tube wells in the study area is totally free from arsenic contamination, as none of the sample has exceeded the WHO, 2011 [10] standard. 68\% and 44\% shallow tube well samples exceed standard limit of arsenic set by WHO, 2011 [10] and DoE, 1997 [2] respectively. Based on the WQI values, the ground water quality is rated as excellent, good, poor, very 
poor, and unsuitable for human consumption (Table 2). For computing WQI, three steps were followed. In the first step, each of the 11 parameters has been assigned a weight $\left(\mathrm{w}_{\mathrm{i}}\right)$ according to its relative importance in the overall quality of water for drinking purposes as shown in Table 2. The maximum weight of 5 has been assigned to the parameters depending on their major importance in water quality assessment.

In the second step, the relative weight $\left(W_{i}\right)$ is computed from the following equation:

$\mathrm{W}_{\mathrm{i}}=\mathrm{w}_{\mathrm{i}} / \sum \mathrm{w}_{\mathrm{i}}$

Where, $W_{i}$ is relative weight, $w_{i}$ is weight of each parameter and $n$ is number of parameters. The calculated relative weight $\left(W_{i}\right)$ values of each parameter are shown in Table 2.

Table 2. Relative weights of the parameters used in WQI calculation [3].

\begin{tabular}{llll}
\hline Parameters & WHO Standards & Weight $\left(\mathrm{w}_{\mathrm{i}}\right)$ & Relative Weight $\left(\mathrm{W}_{\mathrm{i}}\right)$ \\
\hline $\mathrm{pH}$ & 8.5 & 4 & 0.108 \\
Total Hardness & 500 & 2 & 0.054 \\
$\mathrm{TDS}$ & 1000 & 4 & 0.108 \\
$\mathrm{Na}^{+}$ & 200 & 2 & 0.054 \\
$\mathrm{Ca}^{2+}$ & 200 & 2 & 0.054 \\
$\mathrm{Mg}^{2+}$ & 150 & 2 & 0.054 \\
$\mathrm{Cl}^{-}$ & 250 & 3 & 0.081 \\
$\mathrm{SO}_{4}{ }^{2-}$ & 250 & 4 & 0.108 \\
$\mathrm{NO}_{3}{ }^{-}$ & 50 & 5 & 0.135 \\
$\mathrm{Fe}$ & 3 & 4 & 0.108 \\
$\mathrm{As}$ & 0.01 & 5 & 0.135 \\
\hline & & $\sum \mathrm{w}_{\mathrm{i}}=37$ & $\sum \mathrm{W}_{\mathrm{i}}=0.99$
\end{tabular}

In the third step, a quality rating scale ( $q$ i) for each parameter is assigned by dividing its concentration in each water sample by its respective standard according to the guidelines laid down in the WHO (2011) [10] and the result is multiplied by 100, by the following formula:

$$
\mathrm{q}_{\mathrm{i}}=\left(\mathrm{C}_{\mathrm{i}} / \mathrm{S}_{\mathrm{i}}\right) \times 100
$$

where, $q_{i}$ is quality rating, $\mathrm{C}_{\mathrm{i}}$ is concentration $(\mathrm{mg} / \mathrm{L})$ of each chemical parameter in each water sample.

Table 3. Water quality classification based on WQI value [3].

\begin{tabular}{lll}
\hline WQI Value & Class & Water Quality \\
\hline$<50$ & I & Excellent \\
$50-100$ & II & Good Water \\
$100-200$ & III & Poor Water \\
$200-300$ & IV & Very Poor Water \\
$>300$ & V & Water unsuitable for drinking \\
\hline
\end{tabular}


Water Quality Index (WQI) value (Table 3) shows that, most of the groundwater samples of deep aquifer (55\%) have good water quality than shallow aquifer (36\%) and $24 \%$ groundwater samples from shallow tube well is unsuitable for drinking while only 9\% deep tube well samples are unsuitable. Pie diagram (Fig. 8) shows the percentages of groundwater samples found from different sources fall under water quality range.

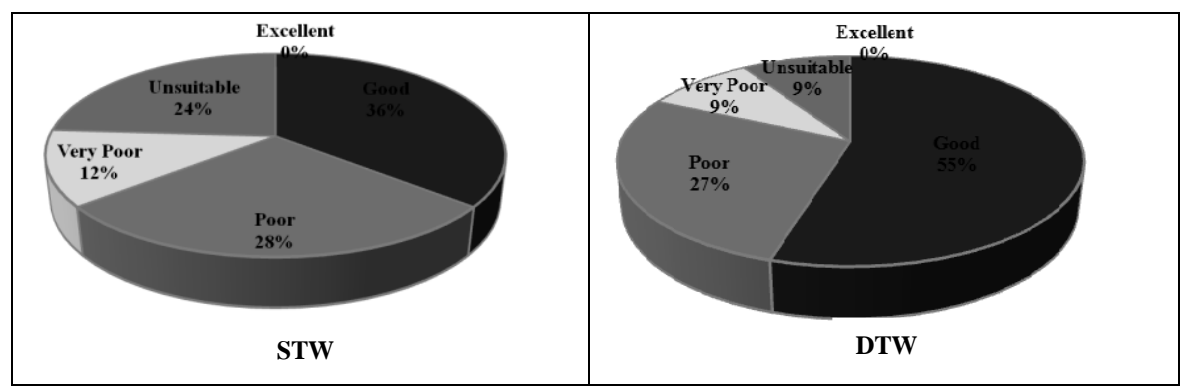

Fig. 8. Percentages of groundwater samples in shallow tube wells (STW) and deep tube wells (DTW) for water quality.

\subsection{Discussion}

Various techniques such as GIS and remote sensing, field investigations, borelog analysis, chemical analysis of groundwater samples were used to map the peat layer of BaghiaChanda Beel and its relation to aquifer geometry and groundwater quality.

Aquifer geometry: The area is underlain by 5 to 10 feet unconsolidated alluvium, which overlies 5 to 9 feet thick peat occurring within the depth of 5 to 15 feet from the ground surface. The Late Pleistocene to Holocene deposits forms major aquifers beneath recent floodplains and is represented by the Chandina Formation as well as the Dhamrai Formation [11]. They are composed of grey micaceous, medium to coarse sands and silt with organic mud and peat. The lithological analysis of the borelogs indicates that there are two regionally extensive grey to light brown silty-clay deposits throughout the peat basin within the depth of $135 \mathrm{ft}$. The peat layer occurred between these two silty-clay beds. South-eastern portion of Rajoir upazilla showed the maximum thickness of peat ( 9 $\mathrm{ft}$ ) whereas in the southern portion of Rajoir and Kotalipara, it is about 5 feet thick. The top clay bed that lied above the peat is 5 to $10 \mathrm{ft}$ thick. The bottom clay occurred with an extensive thickness occurred between 15 to $135 \mathrm{ft}$ and the depth gradually decreased southward. The principal productive shallow aquifer is found just below this bottom clay layer and it is composed of mainly medium to coarse sand.

Groundwater chemistry: The chemical composition of the groundwater showed considerable variations between the shallow and deep aquifer system. The groundwater from the shallow aquifer $(<250 \mathrm{ft})$ below the peat layers are enriched with bicarbonate $\left(\mathrm{HCO}_{3}{ }^{-}\right)$, nitrate $\left(\mathrm{NO}_{3}{ }^{-}\right)$and arsenic (As) whereas the samples from deep aquifer $(>600 \mathrm{ft}$ ) 
are low in $\mathrm{HCO}_{3^{-}}, \mathrm{NO}_{3^{-}}$but relatively high in sodium $\left(\mathrm{Na}^{+}\right)$and chloride $\left(\mathrm{Cl}^{-}\right)$ concentrations.

A clear enrichment of the bicarbonate $\left(\mathrm{HCO}_{3}{ }^{-}\right)$concentration is observed in the shallow aquifer (180-220 ft depth) and much lower values in the deep aquifer (Figs. 5a and 5b). Such enrichment of $\mathrm{HCO}_{3}{ }^{-}$in the shallow aquifer is most likely due to the oxidative degradation of natural organic matter (peat) as shown in the following reactions:

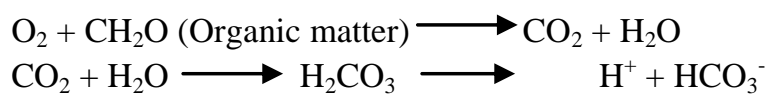

Concentrations of $\mathrm{HCO}_{3}{ }^{-}$also show a distinct relationship with the thickness of the peat layer (Fig. 9). The area with maximum peat thickness (8-9 ft) showed very high concentrations of $\mathrm{HCO}_{3}^{-}(>700-1400 \mathrm{mg} / \mathrm{L})$ whereas relatively low $\mathrm{HCO}_{3}^{-}$(600-700 $\mathrm{mg} / \mathrm{L})$ where peat thickness is less $(5-6 \mathrm{ft})$.

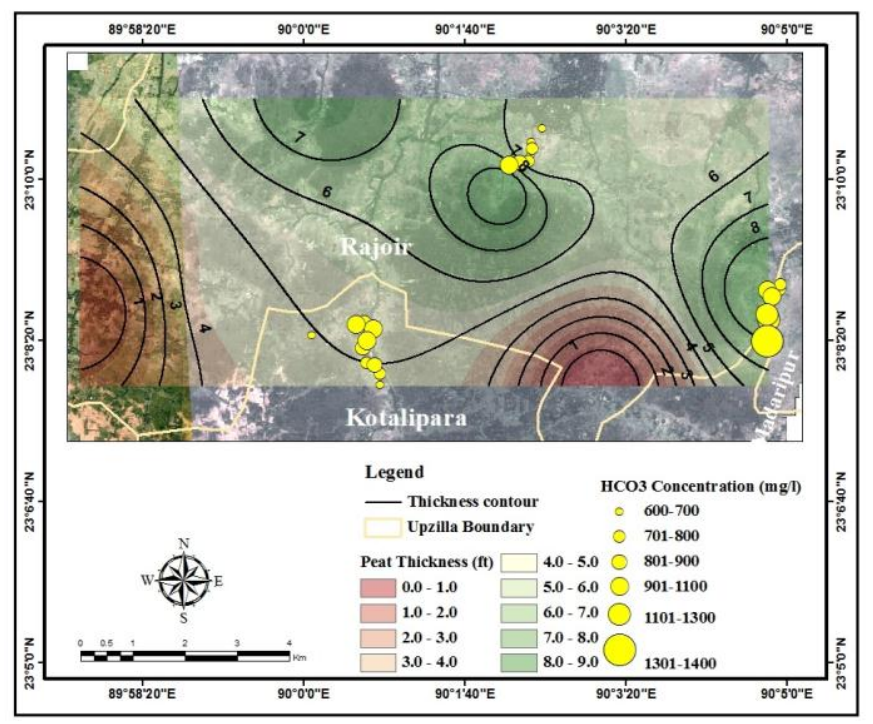

Fig. 9. Variations of groundwater chemistry in relation to peat thickness.

It is postulated that decompostion of peat by microorganism caused a reducing environment in the shallow aquifers and initiated reductive dissolution of iron oxyhydroxide $(\mathrm{FeOOH})$ and release of adsorbed arsenic (As) into the groundwater as indicated by very negative $E h$ value ( -45 to $-95 \mathrm{mV}$ ) and high concentrations of As (50$150 \mu \mathrm{g} / \mathrm{L})$ in the groundwater. Microbial decomposition of natural organic matter and reductive dissolution of $\mathrm{FeOOH}$ is a well-established hypothesis for mobilization of As in groundwater of shallow aquifers of the Bengal basin [4,5,12]. 
Source of high nitrate $(18-80 \mathrm{mg} / \mathrm{L})$ in the shallow aquifer is most probably anthropogenic, i.e. from chemical fertilizer and manure used in agriculture and/or from human and animal wastes.

In the contrary, low $\mathrm{HCO}_{3}{ }^{-}(335-518 \mathrm{mg} / \mathrm{L}), \mathrm{NO}_{3}{ }^{-}(<10 \mathrm{mg} / \mathrm{L})$ and $\mathrm{As}(0 \mu \mathrm{g} / \mathrm{L})$ in the deep aquifer suggest no or little influence of peat and anthropogenic pollution in the groundwater. However, relatively high concentration of $\mathrm{Na}^{+}$and $\mathrm{Cl}^{-}$in the deep groundwater is most likely originated from mixing with ancient seawater trapped in aquifers in geologic past when the coast line was ahead of the present position. The influence of seawater in the deep aquifer is indicated by the source rock deduction described earlier in hydrogeochemistry.

Water quality: The groundwater samples of peat basin are assessed for the water quality in terms of their potential for drinking. Total dissolved solids (TDS) and hardness of most of the groundwater samples do not meet the water quality standards of WHO, 2011 [10]. Sodium $\left(\mathrm{Na}^{+}\right)$and chloride $\left(\mathrm{Cl}^{-}\right)$ion concentrations are generally high compared to other cations and do not meet the water quality standards of WHO, 2011) [10]. Some of the groundwater samples of shallow tube well exceed guideline values of nitrate $\left(\mathrm{NO}_{3}{ }^{-}\right)$concentrations set by WHO, 2011 [10]. The concentrations of iron $(\mathrm{Fe})$ in the few shallow groundwater samples are higher than recommended levels. The measured concentrations of arsenic in most of the shallow groundwater samples are above WHO, 2011 [10] standard limit. Water Quality Index (WQI) value shows that, most of the groundwater samples of deep aquifer (55\%) have good water quality than shallow aquifer (36\%) and $24 \%$ groundwater samples from shallow tube well is unsuitable for drinking while only $9 \%$ deep tube well samples are unsuitable.

\section{Conclusion}

The largest peat deposit of Bangladesh is occurring in the low-lying wet basin of BaghiaChanda Beel at very shallow depth with silty clay layer above the peat. Thickness of the peat varies from 5 to 9 feet. The shallow aquifer, which is the main source of groundwater for domestic use, occurred below this peat layer and is separated from the peat layer by a thick clay layer. The groundwater chemistry clearly indicated the influence of peat layer in the shallow aquifer with very high concentrations of bicarbonate and arsenic in water. Water quality assessment from calculation of WQI for drinking purposes suggested that the groundwater from deep aquifer of the study area are more suitable for drinking purposes than that of the shallow aquifer.

\section{References}

1. B. Imam, Energy Resources of Bangladesh (2005) pp. 239-240.

2. DOE (Department of Environment, Government Republic of Bangladesh, 1997).

3. C. R. Ramakrishnalah, C. Sadashivalah, and G. Ranganna, 6(2), 523 (2009). http://dx.doi.org/10.1155/2009/757424 
4. M. A. Hasan, P. Bhattacharya, O. Sracek, K. ,M. Ahmed, M. von Brömssen, and G. Jacks, J. Hydrol. 378, 105 (2009).

http://www.sciencedirect.com/science/article/pii/S0022169409005678

5. K. M. Ahmed, P. Bhattacharya, M. A. Hasan, S. H. Akhter, S. M. M. Alam, M. A. H. Bhuyian M. B. Imam, A. A. Khan A, and O. Sracek, Appl. Geochem. 19(2), 181 (2004). http://dx.doi.org/10.1016\%2Fj.apgeochem.2003.09.006

6. J. M. McArthur, P. Ravenscroft, S. Saofiulla, and M. F. Thirlwall, Water Resources Res. 37(1), 109 (2001). http://dx.doi.org/10.1029/2000WR900270

7. A. M. Piper, Am. Geophysics. Union Trans 25, 914 (1944). http://dx.doi.org/10.1029/TR025i006p00914

8. A. W. Hounslow, Water Quality Data: Analysis and Interpretation (CRC Press, 1995).

9. J. W. Lloyd and J. A. Heathcote, National Inorganic Hydrochemistry in Relation to Groundwater: an Introduction (Oxford: Clarendon Press, New York, 1985).

10. WHO, Guideline for Drinking Water Quality, $4^{\text {th }}$ edition (World Health Organization, Geneva, 2011) 1.

11. M. K. Alam. A. K. M. S. Hasan, M. R. Khan, and J. W. Whitney, Map of Bangladesh. Geological Survey of Bangladesh, Dhaka (1990).

12. R. Nickson, J. M. McArthur, P. Ravenscroft, W. G. Burgess, and M. Ahmed, Appl. Geochem. 15(4), 403 (2000). http://dx.doi.org/10.1016/S0883-2927(99)00086-4 